\title{
Anne-Marie $\mathrm{Mai}$
}

\section{Indeni - udenfor}

\section{Om Kirsten Thorups forfatterskab i litteraturhistorieskrivningen}

Det vrimler med danske litteraturhistorier! I det første tiår af det 21. århundrede er der en håndfuld nye danske litteraturhistorier på gaden eller på vej. I en tid hvor genren både nationalt og internationalt har været sendt til tælling i litteraturvidenskabens teoretiske boksering, har lysten til at gøre forsøget med at skrive litteraturhistorie grebet både yngre og ældre litteraturforskere. "En national litteraturhistories formål er og var at nationalisere børn og bønder" - lød det advarende fra den polemiske litterat Hans Hauge allerede i 1988. Værre og mindre politisk og videnskabeligt korrekt kunne det næppe blive i 1980'erne, hvor mange af nutidens akademikere og litteraturhistorieskrivere var under uddannelse.

Hauge så i stedet en postnational flersproget litteraturhistorie for sig, lykkeligt befriet fra nationalstaten og først og fremmest for alle institutter for nordisk sprog og litteratur! En postnational litteraturhistorie burde vise, at Danmark er et europæisk land med mange indvandrere og en fortid som et multikulturelt imperium. Mens Hauge var modstander af en national litteraturhistorie, men altså for en postnational ditto, havde andre, internationale teoretiske trendsættere længe været kritikere af genren som sådan. ${ }^{2}$ Traditionel litteraturhistorieskrivning har ikke ret meget at gøre med litteratur, mente allerede en af dekonstruktionskritikkens founding fathers, Paul de Man. Med teoretisk konsekvens erklærede de Man i 1971, at tekstanalyse i højere grad kunne betragtes som litteraturhistorie eftersom historisk viden ikke baserer sig på empiriske fakta, men på skrevne tekster, hvad enten de maskerer sig som krige eller revolutioner. ${ }^{3}$

Den vældige trang til litteraturhistorieskrivning, der trods alskens teoretiske kvababbelser har grebet mere eller mindre poststrukturalistiske og postnationale litterater på dansk grund, finder sted parallelt med den lange kamp om kanon, som Bertel Haarders kanonudvalg skød i gang i 1994. I 1994 gik kanondebatten i sig selv, da Bertel Haarder gik af. Men da de borgerlige støttet af Dansk Folkeparti kom til magten i 2001, fik kanonkampen sin anden luft, og den nåede et nyt højdepunkt med undervisningsministeriets offentliggørelse af den officielle, lovpligtige danske 
kanon i 2004. I 2006 kom der ekstra krudt i kanonen, da kulturministeren afslørede sin kæmpekanon, der skulle kunne ramme alle kunstarter til alle tider.

I litteraturen er og var meget på spil: nye og ældre forfatteres overlevelse eller glemsel i en fælles erindring om dansksproget litteratur sammen med mange litteratur- og forlagspolitiske interesser. Hvem ville komme hurtigst frem til trykkemaskinen og i øvrigt score kassen på undervisningsbøger til den nye kanon? Og er det linien fra Holberg til Brandes og Rifbjerg, der er hovedsporet i dansk litteratur, hvorom kanon og erindring skal struktureres? Hvor efterlader et sådant hovedspor Leonora Christina, Schack von Staffeldt, Søren Kierkegaard og H. C. Andersen? Hvad sker der med samtidslitteraturen? Bortdømmer den vilde kanonjagt og den nye litteraturhistorieskrivning de forfatterskaber, som kritikken og den danske modernismekonstruktion har haft svært ved at tumle? Her er blandt andet den litteraturhistoriske skæbne for Kirsten Thorups forfatterskab interessant at studere og også forsøge at reformulere.

Kirsten Thorup er hverken med på Ulla Tørnæs' eller Brian Mikkelsens kanon. Hun er helt sat uden for døren såvel i det ene som det andet ministerium. Tørnæskanonen slutter som bekendt med forfatterskaber med debut før 1965. Her har man på forhånd bekvemt sikret sig mod overhovedet at skulle tage stilling til opbruddet fra modernismen. Kanon begynder med folkeviserne og Holberg og slutter med Rifbjerg, så alt kan blive ved at være, som det plejer. Hvornår kanon skal ændres, er nemlig blevet en politisk beslutning, der kun kan træffes af en minister eller et flertal i Folketinget. Læserpublikum, kritikere, lærere, undervisere og forskere er som andre grimme smagsdommere helt sat ud af det nye politiske spil om ændringer af det klippefaste litteraturpensum i undervisningen. Brian Mikkelsens kanon tager så småt hul på opbruddet fra modernismen. Både i form af forfatterskaber og tekster fra tiden efter 1965. Man nøjes dog på forfattersiden forsigtigt med at inkludere Henrik Nordbrandt, der debuterede i 1966, i lyrikantologien. Men på tekstsiden går man gerne frem i tid. Den nyeste tekst, der er med på Mikkelsen-kanonen, er Inger Christensens sonetkrans, Sommerfugledalen, fra 1991. I lyrikantologien har Erik A. Nielsen virkelig fået sat fede streger under sin forkærlighed for den symbolistiske linie i dansk lyrik fra Claussen til Bjørnvig, Inger Christensen og udvalgte sider af Højholt. Henry fra Højholts Turbo (1968) ville aldrig få lov at komme ind i dette landskab for slet ikke at tale om de omvandrende ører, Auricula (2001). Der bliver i det hele taget ingen plads til prosa eller lyrik, der går i mere eksperimenterende retninger på tværs af genrer. Thorups tidlige bøger fra slutningen af 1960'erne, der konstant krydser grænsen mellem lyrik og prosa ville forstyrre det nydelige genrebillede. Eftersom der ikke er blik for det 20. århundredes romankunst og slet ikke for hverken den eksistentielt-narrative eller den konstruktivistiske roman, ${ }^{4}$ er der selvfølgelig heller ikke plads til Kirsten Thorup.

\section{På kanten}

Hvordan står så Kirsten Thorups forfatterskab i litteraturhistorieskrivningen? Tingenes tilstand minder mest om Brorsons 1700-tals-salme, "Jeg gaaer i fare, hvor jeg gaaer”. Forfatterskabet balancerer nemlig trods læseropbakning og Thorups store 
gennembrud i den litterære kritik med Himmel og helvede (1982) på yderkanten af den litteraturhistoriske tænkning som en blandingsform, litteraturhistorieskriverne ikke rigtig kan få hold på. Skrækscenariet for forfatterskabet finder vi i Søren Graversens og Steen Hvorslev Mogensens Saxo \& Co. (2003), der er tænkt til brug i de gymnasiale uddannelser, på HF og VUC. Hos Saxo \& Co. er Thorup end ikke nævnt. Konstruktionen af den nyere litteraturhistorie bygges over den velkendte vekseldrift mellem modernisme og realisme, og de centrale figurer blandt "de første postmodernister", der kommer lige efter konfrontationsmodernisterne, er Svend Åge Madsen og Dan Turèll. I afsnittet “Eksistentialisme og postmodernisme 1945-2000” er i øvrigt ikke en eneste kvinde blandt de forfattere, der får et særskilt afsnit. Hverken Dorrit Willumsen, Kirsten Thorup eller Vibeke Grønfeldt bliver omtalt. Inger Christensens forfatterskab får lige en litteraturhistorisk "rundbarbering" over to gange tre linier.

Fremstillingen bæres af den ulyksalige modstilling af modernisme og realisme, som gør det af med så meget god og nybrydende litteratur i litteraturhistorieskrivningen. Man finder også modstillingen i fuldt flor i Johannes Fibigers og Gerd Lütkens Litteraturens veje, anden udgave 2003, hvor Kirsten Thorup og Dorrit Willumsen placeres som "psykologisk realisme" i afsnittet "1970'erne: Fra Woodstock til Vietnam". Det hedder her om Kirsten Thorup og Willumsen: "De skriver ikke litteratur som diskussionsindlæg i kønskampen, og de har begge et udgangspunkt i en modernistisk tradition, der dog med årene omformes til en bredere realisme. Begge har de sans for at skildre psykologisk indviklede spil, at få personer til at leve indefra og ikke gennem den ydre karakteristik. Deres realisme kan betragtes som en psykologisk realisme, og de mestrer begge en fin portrætteringskunst." ${ }^{5}$ Ærgerligt nok har vi stadig modstillingen, "realisme" og "modernisme" på slæb i det nye årtusind. I Hovedsporet. Dansk litteraturs historie (2005) forsøger man sig med et opbrud fra modernismen, inspireret af som det hedder "nyere forsknings ihærdige fremgravning af den eksperimenterende 70' er-digtning", ${ }^{6}$ men en sammenhæng og linie i nybruddet bliver det svært at få fat i, når Hovedsporets forfattere under overskriften "Med andre øjne" udnævner Kirsten Thorup til at være en realistisk forfatter, Suzanne Brøgger til en genrehybrid bekender og Bent Vinn Nielsen til en indignationsforfatter. Det er ikke sært, at der her kun kan blive plads til at namedroppe Vibeke Grønfeldt og Henrik Bjelke under den hjemmestrikkede betegnelse socialmodernister! Hvis en forfatter hverken kan kaldes renlivet modernist eller ditto realist havner forfatterskabet nemt i en farlig gråzone.

Man kan sige, at den udskrivning af litteraturhistorien, som Saxo \& Co effektuerer over for Thorup, truer i flere af de øvrige fremstillinger. Mens Dan Turèll begynder at blive kanoniseret som en tidlig postmodernist med sin forvandling fra "svær modernistisk forfatter til mediekæledægge", 7 glider Kirsten Thorup ned i rækkerne blandt 1960'ernes nye forfattere. Hovednavnene i Hovedsporet er: Hans-Jørgen Nielsen, Inger Christensen, Svend Åge Madsen og Jens Smærup Sørensen, mens det i Litteraturens veje entydigt er Hans-Jørgen Nielsen, "generationens seismograf", som han kaldes. Hvad skal man stille op over for disse konstruktioner af den nyere litteratur og over for to kanoner, der i udtalt grad centrerer sig om 1800-tallets moderne gennembrud og vælger at glemme det meste af det 20. århundrede? Kan Thorup blive en hovedperson i den nyere danske litteraturhistorie? Og hvordan ser 
litteraturhistorien i givet fald ud? Fortsættelse følger i næste afsnit af den litteraturhistoriske soap!

\section{Fra kritik til litteraturhistorie}

Der er sikkert flere grunde til, at man som læser af litteraturhistorierne sidder med livet i hænderne, når det gælder den noget rutschende placering af Thorups forfatterskab.

En årsag til miséren kunne ligge i kritikkens bedømmelse af forfatterskabet. Kritikken er i nutiden litteraturhistorieskrivningens fødekæde. En forfatter, der får forrang i den litterære kritik, har en god chance for litteraturhistorisk og kanonisk overlevelse. Thorup har ofte oplevet en storslået modtagelse og er blevet prisbelønnet som en mesterlig fortæller. Men der har også været mislyde og paradokser, som kritikken aldrig rigtigt har kunnet bide i sig. De lod sig blandt andet høre i forbindelse med romanen Elskede ukendte (1994). Hverken den kulturradikalt eller den modernistisk sindede kritik var udelt begejstret for denne vilde fortælling, som blev kaldt alt fra et forlist projekt til monotoni. Den mest rosende bemærkning lød som følger: "en masochistisk fornøjelse, som det står enhver frit for at unddrage sig" (John Christian Jørgensen i Politiken, 17.3.1994). Bonsai (2000) blev genstand for et regulært og ganske umotiveret overfald for være "hæmningsløst selvbiografisk" af Erik Skyum-Nielsen i Information. Skyum-Nielsen påtvang således hårdhændet Thorup en selvbiografisk kontrakt, som teksten selv ikke indbød til. ${ }^{8}$ Marie Tetzlaff var forsigtigt forbeholden over for Thorups persontegning i en ellers rosende anmeldelse: "Der er altid nogle mærkelige modsigelser i Kirsten Thorups persontegning, og man skal ikke være for smålig med hensyn til hendes hovedpersons udvikling fra den næsten debilt naive, men dygtige studerende Nina til den klarsynede, kendte forfatter, der håndplukkes af en fremstormende svensk filminstruktør som manuskriptforfatter på hans livs film" (Politiken, 26.10.2000).

Kritikken retter sig karakteristisk nok ofte mod form og formelle forhold. Det gælder også romanen Ingenmandsland (2003), der midt i mange roser og den store læserkåring i forbindelse med BG Banks litteraturpris blev kritiseret for både at spænde formen for hårdt $\mathrm{i}$ en halsbrækkende kompositionsform og være for lidt eksperimenterende. Kritikken vil gerne klappe ad Thorups temaer om identitet, kærlighed, køn, galskab og alderdom, men der er og bliver "noget" omkring formen, som flere kritikere ikke rigtig har kunnet komme overens med. Romanernes måde at være romaner på gør vejen fra litteraturkritisk hyldest til de litteraturhistoriske overskrifter vanskelig. Hvis man skal ind med de store typer og selvstændig omtale i den gældende litteraturhistorieskrivning som prosaist, ser det ud til, at man skal placere sig i en psykologisk realisme med indbygget kritik af småborgerlig kultur som Rifbjergs Den kroniske uskyld og Hans-Jørgen Nielsens Fodboldenglen. Man kan dog også praktisere en underholdende fantastik som Svend Åge Madsen. Derfor forsøger mange litteraturhistorikere så ihærdigt at putte Thorups forfatterskab ned i den meget store kasse: psykologisk realisme.

Når det gælder Kirsten Thorup er min pointe imidlertid den, at det netop er formens dristighed, der burde placere Thorup som en hovedperson i den litteraturhi- 
storiske fortælling. De konstruktioner omkring realisme og modernisme, som såvel mange kritikere som et flertal af litteraturhistorikere tænker i, trænger til en kritisk revision, så der kan skabes bedre kritiske og litteraturhistoriske formidlingsformer af forfatterskaber som Kirsten Thorups.

\section{Midt i historien}

Det er selvfølgelig ganske umuligt at give et fyldestgørende historisk billede af samtidslitteraturen. Den udspiller sig og forandrer sig jo for øjnene af læseren. Vi er midt i en historisk kontekst, og Kirsten Thorup har forhåbentlig stadig mange bøger for sig. Romanen Førkrigstid er netop udkommet her i efteråret 2006. Men det er dog snart 40 år siden hun debuterede, og linier i den nyere litteratur kan optegnes. Litteraturhistorieskrivningen har faktisk altid nøje forholdt sig til sin samtids litteratur i sit fors $\varnothing g$ på overhovedet at skabe forbindelse mellem "litteratur" og "historie", selv om vidt forskellige historiske perioder har anset forbindelsen for umulig. Et nyt eksempel på en formulering af modsætningen mellem litteratur og historie finder vi på dansk grund i Torben Brostrøms præsentation af bind III i Kanon i dansk (2006), hvor det bliver understreget, at det er en af modernismens erfaringer, at kunsten altid begynder forfra og altid undersiger alle vedtagne dogmer, æstetiske, religiøse og politiske. Den udsletter dermed konstant sin egen forhistorie - alt er og alt bliver modernisme. Dylans faderlige omkvæd, "Forever young", fra 1974 kunne således være modernismens afskedsreplik til historien. Måske er det denne udmattende søgen efter aktualitet og samtid, der får Jørgen Leth til i et af sine digte i samlingen Det gør ikke noget (2006) at skrive: "Jeg er træt af den gærede sure modernisme."9

Litteraturhistorieskrivningen har forsøgt sig med et umuligt projekt om at komme tilbage til, hvordan det egentlig var, dengang i fortiden, men den har også i høj grad søgt sin motivering og legitimitet i samtidslitteraturen. Der har ofte tegnet sig en art krydsstilling i litteraturhistorieskrivningens tænkning af forholdet mellem fortid og samtid. Litteraturhistorieskrivning er blevet motiveret som et fors $\varnothing \mathrm{g}$ på at forbedre nutidens smag ved at studere fortiden eller som et forsøg på at skabe grundlag for menneskelig identitetsdannelse og frigørelse.

Hvis man forsøger at bruge Thorups værker som en nøgle til en fortolkning og konstruktion af en historisk kontekstualisering af de seneste 40 års litteratur, er det som omtalt ganske oplagt at andre værker og forfatterskaber end de kanoniserede rykker ind i det litteraturhistoriske landskab. Ser man Thorup som en hovedperson i litteraturen siden slutningen af 1960'erne, fokuserer fortællingen om litteraturen langt mere på både eksperimenterende og populær litteratur end traditionelt. Først og fremmest tydeliggør Thorup som historisk hovedperson opbruddet fra modernismen og det formelle gennembruds begyndelse. ${ }^{\text {Io }}$ Modernismen fortsætter netop ikke for evigt, men kulminerer i første halvdel af 1960'erne i Rifbjergs Konfrontation (1960), Ørnsbos Digte (1960), Cecil Bødkers noveller Øjet (1961), Jørgen Sonnes Krese (1963), Uffe Harders Positioner (1964) og Villy Sørensens Formynderfortællinger (1964). Fra midten af 1960'erne formuleres en række andre litterære positioner end modernismens, idet æstetiske skift især i Per Højholts og Inger Christensens forfatterskaber finder sted samtidig med at en stribe unge forfattere på 
tværs af genrer begynder at tematisere litteraturens karakter af i fænomenologisk forstand at være et æstetisk mellemværende mellem den læsende, den skrivende og verden. Denne tematisering spidsformuleres i en række vidt forskellige og forgrenede litterære positioner og programmer - fra dokumentarisme, bekendelseslitteratur, beatdigtning, minimalisme, systemdigtning og nyrealisme til magisk og fantastisk litteratur. ${ }^{\text {II }}$

Det formelle gennembrud er endvidere kendetegnet ved en åbning i forhold til fortidens litteratur og samtidens populærlitteratur og -kultur. Ingen former og temaer er historisk utidige eller upassende efter opbruddet fra modernismen. Det formelle gennembrud skaber netop en samtidighed mellem litterære strømninger af forskelligt historisk ophav. Det er karakteristisk, at flere af de ældre forfattere faktisk senere fået en langt mere direkte adkomst til samtiden end tidligere. I dag viser striben af genlæsninger af efterkrigstidens forfattere, at også litteraturforskningen og kritikken er ved at opdage samtidigheden. Rifbjerg kan slippe ud af modernisme-konstruktionens "ungdomsfængsel” og den evindelige Kroniske uskyld (1958) og læses som forfatter til senere hovedværker som Arkivet (1967), Livsfrisen (1979), Billedet (1998) og Huset (2000). Peter Seebergs forfatterskab genlæses som et af samtidens betydeligste og fokus kan flyttes fra de første bøger til Seebergs senere readymades og mesterværket, romanen Ved havet (1978)..$^{12}$

\section{Kroppen som medie}

Thorups tidlige værker, især digtene Indeni - udenfor (1967), Love from Trieste (1969) og I dag er det Daisy (1971) skriver sig ind i opbruddet fra modernismen og det formelle gennembruds problematik.

I et af de første digte fra Indeni - udenfor ${ }^{13}$ lyder det:

64 Jeg går gennem

mit spejlfri indre -

jeg går udenfor

$i$ et større rum -

svæver og ser intet -

bæres af luftige vækster -

standser ikke -

strander på min krop -

går ind -

ikke for at hvile -

ikke for at synge -

uafgrænset indelukke.

Digtet er hverken verdens eller samlingens allerbedste, men det har alligevel en poetisk styrke og interesse i sin formulering af forholdet mellem jeg'et, det indre, det ydre og digtets udspring. Digtets vigtige og skelsættende vers er vers 8 af de i alt 12: "strander på min krop". Herefter nævnes jeg'et ikke længere, og der kan i vers 12 sættes et bogstaveligt punktum for den friktionsfri bevægelse mellem ydre 
og indre illustreret ved digtets mange tankestreger. Mens jeg'ets indre er spejlfrit, og altså ikke konfronterer jeg'et med en stribe ubevidste skygger, frygtindgydende mudderpramme og fødende og skidende maskiner som i modernismens spejlkabinet, er det ydre heller ikke modernistisk truende eller kuende og synet af "intet" standser lige så lidt som de symbolistiske "de luftige vækster" jeg'et. Bevægelsen gennem luft er så gnidningsfri, at den også minder om en bevægelse gennem vand. Men bogstavrimene i ordene "standses" og "strander" skaber en cæsur i digtets bevægelse, som gør kroppen nærværende og får digtet til at bevæge sig fra sit sjælelige og fysiske lufthav til jordens og kroppens element og billedligt og lydligt strande på et rim. Jeg'et forsvinder i kroppen, "går ind", men resultatet er hverken rekreation ("at hvile") eller poetisk skønsang ("at synge"), men det digt, som står på siden som et paradoksalt "uafgrænset indelukke", som læseren kan opleve igen og igen, og hvorfra den skrivende igen og igen formulerer sig. Selv om digtet står tidligt i samlingen giver det alligevel en form for poetologisk svar på en række af de digteriske og mentale problemstillinger, de øvrige digte kredser om. Mens jeg'et svinger mellem almagt og afmagt i sin omgang med tid og rum, kommer den skrivende til sig selv i digtet, der billedligt danner et "uafgrænset indelukke". Den digteriske skrift etablerer en usikker, men dog følelig balance og samtidighed i relationen krop, bevidsthed og verden, mellem "indeni - udenfor". Digt og krop hører sammen og kan sammenlignes.

Man kan her parallelisere Thorups poetiske udsagn med fænomenologiske forestillinger om krop og perception, om det levende mellemværende mellem subjekt og objekt. Det er netop som et mellemværende, digtene kommer til og bevæger sig tværs over grænsen mellem indeni og udenfor. Den modernistiske modstilling af bevidst og ubevidst, af krop og psyke, af det indre og det ydre, ja selve splittelsestænkningen afløses af poetiske formuleringer af den skrivendes handlen og ageren $i$ et mellemværende med verden og med læseren. Bevidsthed er at være hos tingene ved hjælp af en krop, som Maurice Merleau-Ponty forklarer ${ }^{14} i$ en bestemmelse, der passer godt på en filosofisk problematik i Thorups forfatterskab. Men digtsamlingens og forfatterskabets tematik kan også forbindes med det kulturhistoriske signalement af mennesket som Hans-Jørgen Nielsen når frem til i sit essay "Det aperspektiviske rum" fra Nielsen og den hvide verden: "Mennesket eksisterer ikke mere i et lukket, vertikalt værdihierarki, der bygger på over- og underordning i et sindrigt kassesystem, men i en horisontalt åben verden, der bygger på sideordning." ${ }^{15}$ Digtsamlingen skrives ud fra den erfaring, at der, som Nielsen pointerer, ikke findes en formel, et system, der på perspektivisk vis dækker hele virkeligheden og alle sammenhænge. Der findes ikke et, men mange gyldige billeder af virkeligheden i samtidens aperspektiviske rum. Thorup selv understreger, at hendes kunstneriske problematik og inspiration bliver til med den internationale nybrydende og tværæstetiske kunst fra midten af 1960'erne. Hendes tale til Det danske Akademi i år 2000 markerer på flere måder forudsætningerne for forfatterskabet:

$6($ Samtidig med at en sofistikeret formbevidsthed udviklede 'systemdigtningen' og 'konkretismen', og der opstod en dynamisk dialog mellem folkelighed og avantgarde. Det var i 60'erne min æstetiske lidenskab blev vakt. Ikke som et mål i sig selv, men som vejen ad 
hvilken. Æstetikken som det felt, hvor læseren, beskueren lukkes ind i historien. Mødestedet mellem afsender og modtager. Jeg bliver aldrig færdig med at udforske romanens formsprog og dens æstetiske muligheder. Jeg bliver aldrig færdig med at eksperimentere. I 60'erne havde jeg nogle kunstneriske oplevelser som gjorde et uudsletteligt indtryk på mig, næsten som en åbenbaring. Nogle radikale kunstneriske greb som i dag er gamle travere, men for mig dengang var det noget aldrig før set, som åbnede op for en Pandoras æske. Den polske instruktør Grotowsky gæstede polyteknisk læreanstalt med sit stykke 'The Constant Prince'. Det var teater opført som overværede man et helligt ritual underlagt en slags kirurgisk præcision. Det var første gang jeg så kroppen blive brugt som medie. Og den følelse af at fra nu af er alt muligt inden for kunsten, sidder endnu i mig. Andy Warhols undergrundsfilm 'Chelsea Girls' og 'Empire State Building', den måde han brugte tiden på (også tilskuerens), at han konkretiserede tiden som en del af kunstværket, gav mig den samme følelse af, at der ikke fandtes nogen grænser eller forbud i den skabende proces, kun kunstnerisk nødvendighed. ${ }^{16}$

Især tre bestemmelser er vigtige her: dialogen mellem folkelighed og avantgarde, den nye spidsformulerede relation mellem afsender og modtager i det æstetiske felt eller fænomenologiske mellemværende og konkretiseringen af tiden og begrebet om kroppen som medie.

Det er også bemærkelsesværdigt, at det er dramatik og film, som Thorup beskriver som forudsætningen for sit forfatterskab. Hun har selv både skrevet filmmanuskripter og skuespiltekster. De står ikke voldsomt markant i forfatterskabets helhed, men de to genrer er stærkt til stede i romanværkernes syntetiske måde at danne genre på. ${ }^{17}$ I Ingenmandsland er det meget lange rent dialogiske dramatekster for to stemmer, og i romanerne følger en form for psykologisk-motiverende og generaliserende regibemærkninger ofte karakterernes replikker i selve teksten. “- Det der er galt med dig er, at du ikke egner dig til at være voksen. Du hører til i barndommens rige. Moren holdt hans blik fast. Som ung havde hun været en livlig og tiltrækkende kvinde" - lyder med den karakteristiske teknik en replik mellem Rene og hans mor i romanen Elskede ukendte (1994). ${ }^{\mathrm{I}}$ Det er kendetegnende for Thorup, at man kan henføre det generaliserende regi til en lidt uvis zone mellem moderen og den implicitte fortæller. Der bliver ikke tale om et klart optrukket synsvinkelskift. Replikken kan faktisk placeres både inden i og uden for moderens bevidsthed. Det er både eksempler på, at den generaliserende karakteristik må placeres hos en implicit fortæller, der har en større viden end karakteren, og at generaliseringen tilskrives karakteren som i passagerne af jeg-fortælling i Den yderste grænse: "Vi følger dig jo i tankerne, lille Jonna, sagde Betty. Jeg hadede hendes 'lille Jonna". ${ }^{19}$

Der skabes i Thorups romanværker en art kommunikativt og fysisk flow mellem menneskelige eksistenser, hvor kommunikation og ikke-kommunikation på kroppens, sprogets og bevidsthedens planer tematiseres og udvikles i fortællingen. Over for en moderne og modernistisk analyse af modsætninger mellem det bevidste og det ubevidste, arbejder Thorup med en modstilling mellem karakterens "indeni" og "udenfor" og med gensidige og skiftende tiltrækning og frast ødning imellem mennesker. Den biseksuelle Jonni er delt imellem sit "indeni" og sit "udenfor", og det 
lykkes ham hverken at "strande på kroppen" i mødet med Maria eller med den tyske Herbert.

Karakterernes forandring er ofte knyttet til en symbiose, der opstår og bringes til ophør, og tilfældigheder spinder deres historier sindrigt ind i hinanden. Symbioser forbinder på godt og ondt en række af personerne i Himmel og helvede, og det komplicerer historierne, at symbiosen så langt fra er gensidig. Maria søger den symbiotiske relation med Jonni, mens Johns kærlighed til Maria er uigengældt symbiotisk. Maria tænker om forholdet: "Deres ægteskab var Johns drøm, og hun havde ladet som om hun var gået ind i den. Hun havde en anden drøm inden i sig, som havde hindret hende i at opfylde Johns." ${ }^{20}$ Forholdet til John skaber en "uvirkelighedsfølelse" hos Maria: "Fornemmelsen af at jeg ikke eksisterer, men er en spejling af dig, at jeg er din opfindelse." ${ }^{21}$ Maria på sin side ender i en symbiose med musikken og violinen, som John fra første færd så som sin modstander. Karakterernes navne er ofte variationer over de bibelske navne Johannes og Anna. Johannes kan både opfattes som Johannes Døberen, hvis dåb af Jesus indleder hans lidelseshistorie, og evangelisten Johannes, der i et tilbageblik fortæller hans lidelseshistorie. Anna er jomfru Marias mor, som på sin side låner navn til karakteren Maria. Navnevariationerne peger på, at det er flowet mellem eksistenser og deres symbioser, der sammen med karakterens individualitet interesserer forfatteren. Den mest centrale karakter, Jonna, får en navnekombination af de to betydningsbærende navne, Johannes og Anna. Hendes status som jeg-fortæller lægger endnu en dimension til tematikken omkring "indeni-udenfor". Jonna-jeg'ets uventede forsvinden og lige så uventede opdukken i romanernes forløb peger på fortællerens tematiske og narrative delagtighed i problematikken omkring "indeni-udenfor". Jonna stammer fra en kulturel og mental periferi, et Danmark, der er ved at forsvinde i takt med efterkrigstidens modernisering. Hun lever således både på grænsen til det moderne liv og på grænsen til det postmoderne liv, som hun kommer i kontakt med i storbyen. Fra dette mentale sted i et nyt aperspektivisk livsrum kan hun både falde ind i og ud af romanens univers og lade sin fortælling opsluges af andre bevidstheder end sin egen. Hun er ikke en alvidende fortæller, men en fortællermulighed og ligner måske deri sine læsere.

Man kan endvidere bemærke, at mentale forelskelser er næsten mere hyppige end de kødelige og fysiske hos Thorup, samtidig med at de tydeliggør, at kommunikation er både fysisk og verbal. Replikkerne har fysiske undertekster, og den mentale og seksuelle orientering følges ofte ikke ad. Når den ene karakter føler en virkeligheds- og eksistensoplevelse, føler den anden tomhed og fravær. Historien om den biseksuelle Jonni og musikeren Maria fra Himmel og Helvede er her forfatterskabets arketype.

I ultimative situationer som fødsel og død placeres karaktererne i forhold til elementære fysiske, åndelige og sjælelige begreber om "de sultende", "de udødelige" og "de elskende".

\section{Utopi, dystopi og sammenhæng}

Der er oplagt en utopisk tematik i forfatterskabet. Hver af romanerne har deres ud$\emptyset$ vere af utopiske drømme, der i deres fors $\emptyset \mathrm{g}$ på at realisere utopien aktiverer farlige 
og destruktive sider i sig selv og i omverdenen. Fred i Himmel og helvede udøver ud fra sine hippie-utopier sin grusomme magt, mens Asger i Den yderste grænse ud fra sin politiske utopi om social lighed og frihed ender i vanvid og selvdestruktion. I Elskede ukendte når Karl ud i en vild religiøs fundamentalisme, og i Bonsai fantaserer Stefan i sin dødskamp om en avantgardekunstnerisk utopi, hvor kunst og liv begynder at indgå helt nye forbindelser med hinanden på tankstationerne og rastepladserne. Der er faktisk et helt register af utopier hos Thorup: den kulturelle, den politiske, den religiøse, den erotiske og den kunstneriske. Romanerne viser, hvorledes de alle, idet de søges ført ud i livet, ender som dystopier. Maria og Anna flygter fra den vanvittige Fred, der må formodes at fortsætte med at plage livet af sin kone i en afkrog af verden. Asger slutter sin mission om den nye økonomiske verden med sit selvmord. Karl indretter en art interneringslejr til sin utopis ofre, mens Stefan trækker sin eks-kone og datter ind i et ingenmandsland, hvor hverken død eller liv opleves som realiteter. Begrebet ingenmandsland forbindes gentagne gange i romanerne med de realiserede utopier og deres transformation til dystopier. ${ }^{22}$ Og netop Ingenmandsland (2003) bliver titlen på Thorups roman om den senile Carl, som holdes indespærret på et plejehjem, der helt lever op til den kontroversielle danske standard. Livsaldrene indeholder således også deres problematik omkring utopi og dystopi.

Barndommen kan både være den bedste og den værste af alle verdener hos Thorup, mens alderdommen fører mennesket ind i ingenmandslandet. Moster Marie fra Jonna-serien er dog et eksempel på en karakter, der faktisk oplever opfyldelse i forbindelse med sin død. Hun opdager tilværelsens mønster og gennemfører en slags omvendt syndefald og en tilbagevenden til en forskelsløs tilstand. "Vi har alle planter og dyr i os lige fra de største til de mindste. Vi kan ikke falde ud af mønstret," ${ }^{23}$ tænker hun.

Moster Maries dødsscene indledes med, at hun, der har haft manufakturforretning, forsøger at tegne tilværelsens mønster op på et papir som en fin knipling. Dernæst følger et afgørende gennembrud: "Hun drejede hovedet mod vinduet og så at der ingen forskel var på ude og inde. Hun slog et par streger på papiret for at notere sig denne befriende kendsgerning." ${ }^{24}$ Hun beder om et æble og bevæger sig videre gennem et "overdådigt solskin" som på et gyldent alter, videre til en figuration som en falden, sort engel og ned i en hvid, frossen verden på havets bund, og hun udånder med den barnlige remse på læberne: “'Marie, Marie Marolle flyv op til Vorherre og bed om godt vejr i morgen,' sagde hun med høj og tydelig stemme som om hun sad ved et omstillingsbord." ${ }_{25}$

Referencerne til syndefaldsmyten og til Andersens eventyr, "Snedronningen" og "Den lille havfrue" er tydelige, og Maries forløsning i barneremsen tilsætter en biedermeier-reference, der tager patos ud af skildringen, men samtidig sikrer, at fortællingen bevarer sin billedkraft. Den usædvanlige samling af billedfragmenter gør hvert af elementerne nærværende for læseren og danner et modstykke til den utopiske erfaring hos andre af Thorups karakterer.

Man kan perspektivere de mange utopier, ideen om mønstret og ingenmandslandet i forfatterskabet til Kirstens Thorups bestemmelse af kunstens opgave og funktion i hendes tale til Det danske Akademi i år 2000. Hun erklærer her: 
66Det er en kunstnerisk udfordring at skabe fortællinger i en samtid, der er usammenhængende og også forekommer meningsløs i al sin oppustede rigdom i vores del af verden. En udfordring at skabe sammenhæng ud af en verden opsplittet $i$ et kaos af fragmenter og skabe en betydning ud af det tilsyneladende meningsløse. Tilsyneladende - for bag overfloden findes en endnu større og endnu smukkere verden, som er den kunsten udspringer af. Og det at tage sin tids udfordringer op er netop den trang og den lyst, der driver kunstværket. ${ }^{26}$

Kunsten udspringer af forestillingen om en større og smukkere verden ikke bag syndfloden, men bag overfloden, lyder det. Kunstens utopi har således med skønhed og socialitet at gøre, siger Thorup. Selv om der knytter sig en både forståelse og ømhed til utopisterne hos Kirsten Thorup, dementeres utopierne gang på gang, og utopisterne ender, som vi har set det, med at udøve tvang og vold over for deres medmennesker.

Den kunstneriske "trang og lyst" i forhold til det utopiske har således i lige så høj grad sine skygge- som sine skønhedssider. Thorup er imidlertid også inde på en anden bestemmelse i forbindelse med kunstens opgave: at skabe sammenhæng ud af en verden i et kaos af fragmenter og skabe en betydning ud af "det tilsyneladende meningsløse". Denne ambition er ikke nødvendigvis utopisk, og det er netop begrebet om den sammenhæng, som Moster Marie erfarer, der i forfatterskabet danner et modstykke til utopien. De vilde håb om en bedre verden brister og hærger som dystopier, men der kan - muligvis - formuleres en sammenhæng i kaos og meningsløshed. Sammenhængen kan forstås som den enkelte karakters tolkende fortælling om sin livssituation og livsbane: her træder den eksistentielt-narrative dimension frem i romanerne, og den erfaring, der er central for tolkningen af sammenhængen er erfaringen af "indeni - udenfor". Moster Marie oplever ophævelsen af modsætningen mellem "indeni - udenfor", mens Jonnas usandsynligheder som jeg-fortæller - hendes opdukken midt i tredjepersonsfortællingen og hendes umotiverede forsvinden - peger på hendes stadige konflikt mellem "indeni" og "udenfor": enten er hun fordybet "indeni" i sin indre verden, eller også mister hun sig selv "udenfor" i den ydre verdens mangfoldigheder, dvs. romanernes persongalleri.

Sammenhængen udvikles og undersøges på individets niveau, og de mange tilfældigheder viser, at individers fortællinger faktisk kan og vil blive spundet ind i hinanden netop af det moderne, fortællende menneske, for hvem tilfældet altid både er en mulighed og en fare, når tomrummet efter den traditionelle landsbykultur skal udfyldes. Jonnas og hendes slægtninges liv udspiller sig netop i en kulturel forandring og et opbrud, hvor forskellige livsrum og tidsaldre er blevet samtidige.

Sammenhængen opsøges således også på tidens og omverdenens niveau, og i kraft af den postmoderne samtidighed kommer mange typer af fortællestof og referencer til stede. Thorups litterære univers sammenskriver eventyr, personlige dokumenter som dagbøger, breve og monologer, med scener fra Morten Korch-film, mytestof, dannelsesroman og surrealistiske stills. Verden foreligger i det litterære univers horisonten rundt som en ophobning af vidt forskellige tekster om miljøer, tider og steder. Romanværket bevæger sig ud og ind af overklassemiljø, landsby, hospital, storby, ødemark og underverden. Hos Thorup er omverdenen ikke en hie- 
rarkisk struktur, men et uendeligt netværk af overraskende ind- og udgange til både trivielle og eksotiske miljøer. I Elskede ukendte passerer Rene og Karl en række steder og tider på deres rejse frem mod livets midte. Selv om Rene sandsynligvis for evigt forvises fra universitetets hellige haller, og Karl for bestandig trækkes ud fra sine fattige kår som børnehjemsbarn for at få en opvækst i overklassen, bliver sociale skel forceret - frem og tilbage igen. Mange af Thorups karakterer flytter sig fra underklasse til overklasse, fra land og til by og får smertelige erfaringer i bagagen. Omverdenen er som hos Vibeke Grønfeldt mulighedernes verden, men sjældent med lykke og held som individets udkomme. Både de kulturelle, de politiske og de sociale utopier opstår i dette opbrud og denne åbning af verden, hvor forældregenerationens tilværelsestolkninger, hvad enten de er farvet af landbokultur eller borgerlighed, smuldrer, og nye ideer og forestillinger bliver mulige. Opbrud, utopi og dystopi hænger således uløseligt sammen.

Med Hans-Jørgen Nielsens formuleringer fra Nielsen og den hvide verden (1968) kan man sige, at der hos Thorup ikke findes et gyldigt perspektiv på virkeligheden, den er bare med sine mange værdipunkter horisonten rundt. ${ }^{27}$

Thorups tematik omkring utopien og den aperspektiviske sammenhæng kan genfindes hos en række forfattere fra midten af tresserne og begyndelsen af 1970 'erne, og det er faktisk først når man gør Thorup til litteraturhistorisk hovedperson, at man opdager, hvor gennemgribende det utopiske tema er i samtidens litteratur.

\section{Ud af utopierne}

Det er interessant at parallelisere den utopiske tematik hos Thorup med Suzanne Brøggers tilbagevendende kritiske diskussion af de vesterlandske kærlighedsutopier lige fra hendes debutessays Fri os fra kærligheden (1973) til hendes skuespil Efter orgiet (1992). Suzanne Brøgger har en helt anden retorik og en anden genrebrug end Thorup, men tematisk er der ligheder. Hos Suzanne Brøgger er kritikken af biedermeierkulturens og kapitalismens kønsliv også en kritik af frigørelsesutopierne. I Kærlighedens veje og vildveje (1976) har et stort essay titlen "Ingenmandsland". Betydningen af begrebet er en lidt anden. Mens ingenmandslandet hos Thorup er en transformationszone mellem utopi og dystopi, er det hos Brøgger en alternativ topos i forhold til såvel utopierne som den gældende realitet. Brøgger pointerer, at bevægelsen "udi ingenmandsland er ikke-hierarkisk, ikke-eksklusiv, ikke-fallisk. Den er multi-dimensional. Den siger nej til at være "den anden”, nej til at være "ovenpå", "nedenunder" eller "udenfor" [...] At bevæge sig ud i ingenmandslandet er at nægte at begrænse skaberkraften til at passe inden for rammerne af en bestemt patriarkalsk livsopfattelse eller ideologi." ${ }^{28}$

Som hos Thorup stilles en mulig tilværelsessammenhæng og praksis op som modtræk til utopien: "Fri mig for tidens frigørelsesdogmatik/bind mig til en æblegren/Jeg er vegetativ/Ueffektiv/Jeg gider ikke arbejde/Jeg gider kun flytte et stenbjerg eller to/Jeg er gået i kloster for at lave grundforskning/tænke ikke-tanker/stille ikke-spørgsmål/og analysere ikke-data./Det er ikke mine meningsytringer I skal lægge mærke til,/men mit vidnesbyrd om at der er et andet liv." ${ }^{29}$ I Brøggers univers bliver det fortællerens egen performative insisteren på sit ekspansive vidnesbyrd 
om et andet sammenhængende liv, der strukturerer teksten og værket. Over for alle slags utopier sætter jeg'et sit eksistentielt-narrative projekt, herunder også sine forsøg med at digte sig ind i andre jeg'er og stemmeføringer og en stribe forskellige genrer: brev, interview, strøtanke, essay, novelle, monolog, digt, roman. Derfor finder man også i Fri os fra kærligheden et fiktivt brev fra Lou Salomé til en ung kvindesagskvinde med følgende pointe: "Hvis du gør noget andet, end det der forventes, så digter du. Og så er grænserne for livsytringer blevet udvidet og definitionen af det kvindelige mere vidtfavnende - forandret." ${ }^{3^{\circ}}$ Senere i Brøggers forfatterskab stilles der også spørgsmålstegn ved det selvberoende og selvfremførende individ, og myterne, der hele tiden har været en stærk undertekst hos Brøgger, træder frem som pejlemærker i en sammenhængsskabende tolkningsproces. I det dystopiske skuespil Efter orgiet (1992) om Aids-epidemien skabes der igen forbindelse mellem myte og ritual i en dramaturgi, der også inddrager tilskuerne, idet de forvandles til forestillingens græske kor.

Forholdet mellem modernitet, myte og utopi er et centralt tema hos flere af Thorups jævnaldrende. Jens Smærup Sørensens forfatterskab tematiserer i lighed med Thorups og Brøggers 1960'ernes og 1970'ernes ungdoms- og oprørserfaringer. I debutromanen, At ende som eneboer, 1972, opsluges fortælleren, som Erik Svendsen $^{3 \mathrm{r}}$ har vist, af sin egen tidstolkende virksomhed, og myten og forestillingen om utopia forener sig $i$ et vanvid, der sender fortælleren helt ud af livet og nutiden og tilbage i en mandlig urscene: vejen ind i labyrinten på Knossos.

Polemikken i Smærup Sørensens forfatterskab mod 1970'ernes marxistiske forklaringsiver og sociale idealisering deles af Thorup og Brøgger, men får også en særlig version hos en lidt yngre prosaist Bent Vinn Nielsen. Hans roman Opkøb af dødsboer, 1980, former sig som en nøgtern og grum demontering af 1970'ernes sociale idealisering af arbejder- og underklasse. Familien Klop skildres med reference til kykloperne i Odysseen som både rå og lovløse. En vis flygtig velstand opnår familien i forbindelse med sønnens talent for opkøb af dødsboer. Men tingenes mentale tilstand bliver ikke bedre af den grund, og snart er de usminkede realiteter igen helt på plads. Den eneste følelse, far Ervin nærer, gælder hans termokande: "Det var ikke nogen stor thermokande, men han havde altid været glad for den. Den var god til at holde kaffen varm og af en eller anden grund havde han altid så godt kunne lide at den var skotskternet." ${ }^{2}$ Hvis man afprøver Thorups gamle tese om, at alle mennesker har en fantastisk historie på Vinn Nielsens karakterer, er resultatet mest af alt fantastisk grumt. Der er mindre forsonlighed og mere ironi og moralitet hos Vinn Nielsen ${ }^{33}$ end hos Thorup, men sammenhængen mellem det kulturelle opbrud og dystopien står centralt i begge forfatterskaber.

De mange dystopier i Thorups romaner finder også en pendant i Henrik Bjelkes galskabsromaner, især Saturn (1974) og Hundrede postkort fra helvede (1980), hvor skriften selv er i en lang svimlende bevægelse mellem utopi og dystopi. Bjelkes tekster kunne være forfattet af en af Thorups utopister, idet karakterernes psyke simpelthen ofte er opløst i et felt af utopiske og dystopiske punkter.

Hos Vibeke Grønfeldt gør både moderne mytologi, utopi og dystopi deres indtog i karakterernes omverden og bevidsthed i kølvandet på nedbrydningen af den traditionelle almuekultur. I hendes storværk, Mulighedernes verden, I-II, 1989, styk- 
ker den kunstneriske skrift en verden sammen af historier, situationer, monologer, dialoger og skriftlige readymades. Den kunstneriske skabelsesproces bliver her et modstykke til den dystopi, som fortællingen gang på gang fremholder. En kvindelig fotograf, der er født i år 1900, er en gennemgående figur, som reflekterer over sit livs oplevelser og udvikler sin dystopiske tænkning om mennesket anno 2050. Denne skabning har skinnende ham og en mave som en kemisk fabrik,

W der i løbet af et døgn nedbryder, hvad lys og luft er 1.000.000 år om at hente tilbage. Denne proces vil være det nye menneskes vigtigste funktion. En ny religion kan prædikes for fulde kirker: Den, der æder mest, skal leve videre. I bjerge af grundstoffer. Den, der æder mest, belønnes på jorden. I evighed.

De frembragte gasser vil ikke være ufarlige for mindre tilpasningsdygtige skabninger. Men som en særlig retfærdighed vil det vise sig, at de første ikke igen bliver sidst. Først kvæles de hvirvelløse dyr, leddyr, fisk, padder og krybdyr.

Tilbage bliver de bevægelige pattedyr. Og når solen forsvinder, har vi midler til at søge en større sol. Og en stadig større sol. Og til at tage den blå måne med os. ${ }^{34}$

Thorups kritiske tematisering af utopier og hendes søgende udforskning af en sammenhæng kan endvidere paralleliseres med bestræbelser hos Dan Turèll, Peter Laugesen og Klaus Høeck.

Dan Turèlls forsøg på at nærme sig, hvad han kaldte altings betydningsløse sammenhæng, ${ }^{35}$ finder sted i den stadige improviserende sideordning af storbystemmer, situationer, historier og genrer fra Karma Cowboy (1974) og Vangede billeder (1975). De repræsenterer ligesom Thorups Baby og Himmel og helvede forsøg på at udfolde en aperspektivisk storbyskildring, og også i Turèlls forfatterskab ligger der konstant både et forsøg med og en skarp kritik af utopisk tænkning. Karma Cowboy digter om "en ny krops smeltende tid", ${ }^{36}$ men udpeger samtidig verdens øjeblikkelige åbenhed: “'Hele verden er åben' og det ER den Endnu/ i denne nat er der ingenting der/ikke kan gøres." ${ }^{37}$

Klaus Høecks tematisering af de politiske oprørsbevægelser i værker som Ulrike Maria Meinhof (1977), Topia eller Che Guevara (1978) og Winterreise (1979) tager fat i den marxistiske politiske utopi om social lighed. Jeg'et "forelsker sig håbløst i en ny tabt sag" og påtager sig "forsvaret af Kain": ${ }^{38}$ de desperate unges væbnede kamp mod magthaverne. Deres nederlag og fejltagelser bliver mere og mere åbenlyse, selv om jeg'et hos Høeck søger at formulere et forsvar for deres fremtidshåb, leve sig ind i deres fortvivlelse og skildre deres ensomme endeligt. I Thorups roman Den yderste grænse (1987) tiltrækkes den unge drømmer Bien af den hærgende tyske byguerilla, og Jonna opdager skrækslagent, at hun måske godt kunne se sig selv i Ulrike Meinhof. Jonna tænker om Ulrike: "Hun kunne bare være blevet hjemme i sin store dyre Hamburg-villa i stedet for at gå i krig mod magthaverne. Hun havde overtrådt samfundets allerhelligste tabu: magtens urørlighed. Og det skulle selvfølgelig straffes med døden. For at alt kunne blive som før og intet skulle forandres. Men hvad nu hvis man kom til at se sig selv (eller en del af sig selv) i hende? Den pæne, dygtige pige, der havde stirret sig blind på magten og ladet sig indfange $\mathrm{i}$ magtens ingenmandsland, hvor livet ikke mere var et alternativ, hvor der ikke var 
andet tilbage end at kæmpe til døden. Den pæne, dygtige pige, der havde gjort sig til magtens bagside, dens skygge. Og var blevet fremmed for alt menneskeligt." ${ }^{39}$ Det er en sådan fremmedfølelse, jeg'et hos Høeck konfronterer sig med, på sin vej ned gennem Tyskland, den kuldsejlede katedral med "vredens og nattens sarkofag"40. De følgende samlinger af Høeck, Canzone. Digte fra Nørrebro (1981) og Metamorfoses (1983) tager afsked med den politiske, utopiske tænkning og dens dystopiske realitet, og lader "poesiens metode", som det lyder i Winterreise, åbne omverdenen og skabe jeg'ets nøgterne tilstedeværelse i en uforklarlig og paradoksal sammenhæng af ånd og realitet.

Den utopiske og dystopiske tematik er ligeledes til stede i Peter Laugesens digtning, hvor skriftens konkrete åbnende og legende forløb danner et modstykke til samfundstilstandens og den politiske tænknings stivnen i magt og selvretfærdighed. "Den ondskab/der bunder i at man er den/der har ret/ at man er den sunde rigtige sande/ det er nok bare ikke den mest almindelige/men den eneste på alle planer/ fra sovekammer skriveborg og våbensal/fra talerstol og slagmark" - lyder det eksempelvis i Konstrueret situation (1996). En i positiv forstand anarkistisk tilgang til omverden og medmenneske præger Laugesens digtning og er måske et fællestræk for hele generationen fra slutningen af 1960' erne og begyndelsen af 1970'erne.

Thorups kunstneriske pointe og drivkraft er som omtalt ideen om, at alle mennesker, hver og en, har en fantastisk historie. Fortællingerne ligger som Hans-Jørgen Nielsens "værdipunkter" overalt i mennesket, kulturen og sproget og kan opdages og udfoldes.

\section{En litteraturhistorisk hovedperson}

Hvis man som litteraturhistorieskriver sætter Thorup ind som en hovedperson i den nyere litteratur bliver det tydeligt, hvor fremtrædende romaneksperimenter og forsøg på at nå "den yderste grænse" i vilde og store fortællinger faktisk er i den nyere danske litteratur fra Thorup og Vibeke Grønfeldt til Henrik Bjelke, Bent Vinn Nielsen og Jens Smærup Sørensen. Også genrekrydsene mellem lyrik, prosa, dramatik og essayistik er tydelige, når man læser Thorup i sammenhæng med Brøgger, Turèll, Høeck og Laugesen. Dansk litteratur bliver med Thorup som en hovedperson en mere livlig og sammensat størrelse med stærke og klare inspirationer i europæisk og amerikansk litteratur. Tematikken omkring opbruddet fra den gamle landbokultur, som er så stærkt i prosaen i det formelle gennembrud, får også flere dimensioner og opbruddets utopiske og dystopiske problematik bliver tydelig og både politiske, erotiske, kulturelle og religiøse utopier træder frem.

Thorups danske beslægtede er utvivlsomt Herman Bang, men hun har - som hun selv pointerer - stærke forudsætninger i europæisk og amerikansk pop- og avantgardekunst i lighed med mange andre i generationen fra midten af 1960'erne. Thorups indlevede opgør med den utopiske tænkning gennemspilles i hendes store romanværk og en forestilling om menneskets mulighed for performativt at skabe en eksistentieltnarrativ sammenhæng bliver mere og mere fremtrædende, samtidig med at omverdenen antager karakter af at være et åbent netværk af muligheder og faldgruber, en fysisk og mental realitet, som karaktererne på godt og ondt hører hjemme i. 
Måske vinetopi det nyeårtusind, hvor tro og utopiigen såstærkt bindes sammen af forskellige religioner, har nye forudsætninger og et større behov for at læse eksempelvis Thorups mesterlige Elskede ukendte om utopiens forvandling til dystopi og om en grundlæggendemenneskeliglængselefterheltenkeltatmødedetandetmenneske.Den kritiske refleksion over den utopiske tænkning, som kunsten fra midten af 1960 'erne og begyndelsen af 1970'erne har foretaget, er nutidens udfordring til hver og en.

\section{Noter}

I Jf. Hans Hauge: “Ti teser om en post-national dansk litteraturhistorie”, i Kritik 133 (1988).

2 Gode introduktioner til diskussionen om litteraturhistorieskrivningens problematik findes i Lise Busk Jensens artikel "Litteraturhistoriens nytte", i Poetik 6, 1996, og i Mads Rosendahl Thomsens og Svend Erik Larsens antologi Litteraturhistoriografi (Århus, 2005). Mads Rosendahl Thomsens afhandling Kanoniske konstellationer. Om litteraturhistorie, kanonstudier og 1920'ernes litteratur (Odense 2003), analyserer selve kanonbegrebet og kanondannelsen ud fra 1920 'ernes litteratur.

3 Jf. Paul de Man: "Literary History and Literary Modernity", Blindness \& Insight (London, 1983).

4 Jeg skelner meget forsøgsvis og heuristisk mellem tre romanformer i den nyere litteratur ud fra bestemmelser af forholdet mellem individ, tid og rum: den moderne roman, der strukturerer tid og rum omkring det menneskelige subjekt og gør individet til den centrale figur i det litterære univers' betydningsdannelse (et oplagt eksempel er Tage Skou-Hansens Holger Mikkelsen-serie), den eksistentielt-narrative roman, der centrerer sig omkring narrationen og flytter fokus fra individet til fortællingen, der bliver den overgribende figur i forhold til tid og rum (et oplagt eksempel er Svend Åge Madsens Syv aldres galskab) og den konstruktivistiske roman, der strukturerer sig omkring det tilfældige spil af mulige konstellationer mellem figurer, tider, rum og stykker af fortælling (et oplagt eksempel er Kirsten Thorups tidlige værker, Vibeke Grønfeldts Mulighedernes land, 1989, Peer Hultbergs Byen og verden, 1992, eller Helle Helles debut Eksempel på liv, 1993). Den moderne roman fortæller individets historie i tid og rum, den eksistentielt-narrative roman fortæller om fortællingen, der fortæller individet, tiden og rummet. Den konstruktivistiske roman igangsætter tilfældets spil af muligheder i skikkelse af individ, tid, rum og fortælling, idet tilfældet samtidig peger på læseren som betydningsdanner. Det er kendetegnende for Kirsten Thorup og andre prosaister i det formelle gennembrud, at de har arbejdet med de tre romantyper. De tre romantyper er omtalt i artiklen, "Det formelle gennembrud", Danske digtere i det 20. århundrede, bd. III (København, 2000), 549ff.

5 Johannes Fibiger og Gert Lütken: Litteraturens veje (København, 2003), 381.

6 Jens Anker Jørgensen m.fl. (red.): Hovedsporet. Dansk litteraturs historie (København, 2005), 630.

7 Ibid., 613.

8 Jon Helt Haarder kommenterer Skyum-Nielsens biografiske læsning af romanen og betegner den som en destruktiv sproghandling i artiklen, "Lugtede der hjemme hos Villy Sørensen? Om biografiske sproghandlinger og retten til det private”, Kristin Ørjasætter, Henrik Skov Nielsen og Stefan Kjerkegaard: Mellem autofiktion og selvfremstilling (Århus, 2006).

9 Jørgen Leth: Det gør ikke noget (København, 2006), 19.

Io I den afsluttende artikel i bind III, Danske digtere $i$ det 20. århundrede (København, 2000), 
diskuterer jeg en ny periodisering af litteraturen fra midten af 1960'erne til nutiden under overskriften "Det formelle gennembrud".

II Den aktuelle diskussion om selvbiografiske dobbeltkontrakter, som Poul Behrendts bog Dobbeltkontrakten. En æstetisk nydannelse (København, 2006) har rejst, viser lige ind i kernen af det formelle gennembruds problematik om den nyere litteraturs spidsformuleringer af relationen mellem den læsende, den skrivende og verden. Vigtig i diskussionen af den nye forfatterfigur er også Jon Helt Haarders forskning i forfatterfigurens forandringer, blandt andet offentliggjort i artiklen, "Det forhold, vi havde til forfatteren", Norsk Litteraturvitenskapelig Tidsskrift 1 (2005).

I2 Jf. Jørn Erslev Andersens læsning af Ved havet i Anne-Marie Mai, Maria Davidsen og Jørgen Aabenhus (red.): Peter Seeberg \& Hald. At åbne arkivet (Odense, 2005).

I3 Kirsten Thorup: Indeni-udenfor (København, 1967), 11.

I4 Jf. Maurice Merleau-Ponty: Kroppens fænomenologi (København, 1994), 92.

I5 Hans-Jørgen Nielsen : "Det aperspektiviske rum”, i Nielsen og den hvide verden (København, 1968), 20.

I6 Kirsten Thorup: "Vi er landet på en anden planet. Tale til Det danske Akademi", Aktuelt, 4.12.2000.

I7 Man kan bruge Jean-Marie Schaeffers begreb syntetisk generecitet om Thorups romanværker.

I8 Jf. Kirsten Thorup: Elskede ukendte (København, 1994), 47.

I9 Kirsten Thorup: Den yderste grænse (København, 1987) bd. 2, 443.

20 Kirsten Thorup: Den yderste grænse (København, 1987) bd. I, 34.

2I Ibid., 343.

22 Elisabeth Møller Jensen har understreget forfatterskabets dystopiske og apokalyptiske tematik i sit forfatterskabsportræt i Nordisk Kvindelitteraturhistorie, bd. IV, 28-35.

23 Thorup 1987, 459.

24 Ibid., 459.

25 Ibid., 462.

26 Kirsten Thorup: "Vi er landet på en anden planet. Tale til Det danske Akademi", i Aktuelt 4.12.2000.

27 Jf. Hans-Jørgen Nielsen: "Det aperspektiviske rum”, i Nielsen og den hvide verden (København, 1968), 20.

28 Suzanne Brøgger: Kærlighedens veje og vildveje (København, 1975), 164-65.

29 Ibid., 165.

30 Ibid., 105.

3I Erik Svendsen: “Jens Smærup Sørensen”, i Anne-Marie Mai (red.): Danske digtere i det 20. århundrede (København, 2000), bd. III, 188.

32 Bent Vinn Nielsen: Opkøb af dødsboer (Viborg, 1980), 227.

33 Frederik Stjernfelts læsning af Bent Vinn Nielsens forfatterskab i Danske digtere i det 20. århundrede understreger netop den moralske dimension i forfatterskabet.

34 Vibeke Grønfeldt: Mulighedernes verden (København, 1989), bd. II, 300.

35 Dan Turèll: Karma Cowboy (København, 1974/1999), 191.

36 Ibid., 305.

37 Ibid., 273.

38 Klaus Høeck: Winterreise (København, 1979), 187.

39 Thorup 1987, 67.

40 Høeck 1979, 23. 